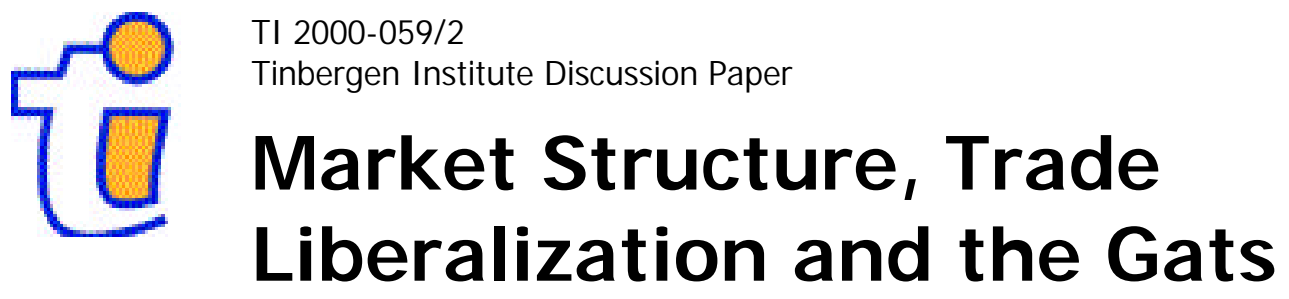

J oseph Francois

Ian Wooton 
Tinbergen Institute

The Tinbergen Institute is the institute for economic research of the Erasmus Universiteit Rotterdam, Universiteit van Amsterdam and

Vrije Universiteit Amsterdam.

Tinbergen I nstitute Amsterdam

Keizersgracht 482

1017 EG Amsterdam

The Netherlands

Tel.: +31.(0)20.5513500

Fax: $\quad+31 .(0) 20.5513555$

Tinbergen I nstitute Rotterdam

Burg. Oudlaan 50

3062 PA Rotterdam

The Netherlands

Tel.: $\quad+31 .(0) 10.4088900$

Fax: $\quad+31 .(0) 10.4089031$

Most TI discussion papers can be downloaded at

http://www.tinbergen.nl 


\title{
MARKET STRUCTURE, TRADE LIBERALIZATION AND THE GATS
}

\author{
Joseph Francois* \\ Tinbergen Institute and CEPR \\ Ian Wooton \\ University of Glasgow and CEPR
}

June 2000

\begin{abstract}
In this paper we examine the interaction between the different modes of market access commitments in services (cross-border and establishment) market structure, and regulation. In this context, we focus on the impact of improved domestic market access for a foreign service provider on a domestic service market. We work with a model where the domestic industry is assumed to be imperfectly competitive and, as a result of domestic regulation, able to act as a cartel. We also examine the incentives for the domestic firms to accommodate the entry of the foreign firm by inviting it to join the cartel.
\end{abstract}

JEL Codes: F12, F13, F23

Keywords: services trade, trade liberalization, market access, imperfect competition

* This paper was prepared for the World Services Congress, Atlanta, GA, November 1999. 


\section{MARKET STRUCTURE, TRADE LIBERALIZATION AND THE GATS}

ABSTRACT: In this paper we examine the interaction between the different modes of market access commitments in services (cross-border and establishment) market structure, and regulation. In this context, we focus on the impact of improved domestic market access for a foreign service provider on a domestic service market. We work with a model where the domestic industry is assumed to be imperfectly competitive and, as a result of domestic regulation, able to act as a cartel. We also examine the incentives for the domestic firms to accommodate the entry of the foreign firm by inviting it to join the cartel.

Key words: services trade, trade liberalization, market access, imperfect competition

JEL classification: F12, F13, F23

CONTACT DETAILS:

Joseph Francois

Faculty of Economics

Erasmus University Rotterdam

Burg Oudlaan 50-H8-26

3062PA Rotterdam NETHERLANDS

voice: +31 104081256

fax: +31 104089146

email: francois@few.eur.nl

homepage: www.intereconomics.com/francois
Ian Wooton

Department of Economics

University of Glasgow

Adam Smith Building

Glasgow G12 8RT SCOTLAND, UK

voice: +441413304672

fax: +44 1413304940

email: i.wooton@socsci.gla.ac.uk

homepage:www.gla.ac.uk/economics/wooton/ 


\section{NON-TECHNICAL SUMMARY}

From its inception, the multilateral trading system has been focused on trade in goods. Hence, from 1947 through the Tokyo Round, services were not covered in successive rounds of trade negotiations. The Uruguay Round, and the subsequent launch of the WTO, changed this. They brought an incorporation of services into the multilateral trading system under the General Agreement on Trade in Services (GATS). However, the actual degree of liberalization has been relatively limited, with many of the GATS schedules involving simple stand-still commitments (or less). It is generally recognized that there still remains significant scope for liberalization in the service sectors.

This paper is concerned with the analytical implications of service-sector liberalization, and in particular the role of market structure. We focus here explicitly on cross-border trade in services, and the interaction of international trade with market structure and public regulation. Of course, in many ways the insights from the theoretical literature on international trade apply equally to goods and services. This is particularly true for cross-border trade. There are, however, some important differences. One is the role of which has important analytical implications. The significance of proximity for service transactions means that "trade" in the case of services often requires a mix of cross-border transactions and local establishment (i.e., FDI). The importance of trade through affiliates is illustrated, for the case of the United States. The United States is the leading service exporter, with $\$ 245.7$ billion in 1998 . The level of U.S. service sales through affiliates (establishment trade) is comparable. Establishment sales amounted to $\$ 258$ billion in 1997 , which compares to $\$ 240$ billion in direct exports.

The empirical and operational importance of establishment leads to a second important difference between goods and services. This is an institutional difference. While the GATT emphasizes barriers at the border (tariffs, quotas, etc.), the GATS has a different focus. From the outset, it has emphasized both cross-border barriers and barriers to local establishment. Consequently, the GATS blurs trade and investment restrictions, and covers both trade and investment rules to the extent that they limit market access in service sectors.

Given the structure of the GATS, negotiations involve parallel commitments on cross-border trade and local establishment by foreign service providers. We argue in this paper that these two modes (a simplification of the four modes actually listed in the GATS) can carry different implications for national welfare, market structure, profits, and related metrics tied to trade liberalization. In particular, given imperfect competition in services (often in conjunction with domestic regulation), realization of gains from trade liberalization is tied closely to issues of market regulation and market structure. This in turn means that assessment of services commitments should take into account market structure and regulatory issues that affect the degree of competition.

Our results point to important linkages between the degree of competition, the mode and degree of market access, and the pro-competitive effects of liberalization. When we introduce establishment in conjunction with low cross-border barriers, we find that the foreign service provider takes on the domestic cartel. This is clearly a pro-competitive result. At higher levels of cross-border trade barriers, establishment may instead lead to an equilibrium where the foreign sector is simply co-opted into the domestic cartel. This has well known negative consequences related to profit shifting. The impact of establishment on the degree of competition, and on potential gains or losses from liberalization, hinges on the underlying degree of competition (a regulatory issue), but also on barriers to cross-border trade. 


\title{
Market Structure, Trade Liberalization, and the GATS
}

\author{
J.F. Francois and I. Wooton
}

\begin{abstract}
In this paper we examine the interaction between the different modes of market access commitments in services (cross-border and establishment) market structure, and regulation. In this context, we focus on the impact of improved domestic market access for a foreign service provider on a domestic service market. We work with a model where the domestic industry is assumed to be imperfectly competitive and, as a result of domestic regulation, able to act as a cartel. We also examine the incentives for the domestic firms to accommodate the entry of the foreign firm by inviting it to join the cartel.
\end{abstract}

JEL Codes: F12, F13, F23

Key Words: services trade, trade liberalization, market access, imperfect competition

\section{OVERVIEW}

From its inception, the multilateral trading system has been focused on trade in goods. Hence, from 1947 through the Tokyo Round, services were not covered in successive rounds of trade negotiations. The Uruguay Round, and the subsequent launch of the WTO, changed this. They brought an incorporation of services into the multilateral trading system under the General Agreement on Trade in Services (GATS). However, the actual degree of liberalization has been relatively limited, with many of the GATS schedules involving simple stand-still commitments (or less). It is generally recognized that there still remains significant scope for liberalization in the service sectors.

This paper is concerned with the analytical implications of service-sector liberalization, and in particular the role of market structure. The trade theory literature has traditionally focused on trade in goods, with the literature on international trade in services being a relatively limited and recent addition. [See, for example, Francois (1990a), Hoekman (1994), Markusen (1988,1989), Sampson and Snape (1985), Stern and Hoekman, (1988), Francois and Schuknecht (1999).] In addition, while there is a sizable empirical literature on service sector policy and deregulation, this is largely focused on domestic deregulation. ${ }^{1}$ In

\footnotetext{
${ }^{1}$ A thorough overview is provided by WTO (1998).
} 
contrast, we focus here explicitly on cross-border trade in services, and the interaction of international trade with market structure and public regulation. ${ }^{2}$

Of course, in many ways the insights from the theoretical literature on international trade apply equally to goods and services. This is particularly true for cross-border trade. There are, however, some important differences. One is the role of proximity (see Francois, 1990b; Sampson and Snape, 1985), which has important analytical implications. The significance of proximity for service transactions means that "trade" in the case of services often requires a mix of cross-border transactions and local establishment (i.e., FDI). The importance of trade through affiliates is illustrated, for the case of the United States, in Table 1. The United States is the leading service exporter, with $\$ 245.7$ billion in 1998 . The level of U.S. service sales through affiliates (establishment trade) is comparable. Establishment sales amounted to $\$ 258$ billion in 1997 , which compares to $\$ 240$ billion in direct exports.

The empirical and operational importance of establishment leads to a second important difference between goods and services. This is an institutional difference. While the GATT emphasizes barriers at the border (tariffs, quotas, etc.), the GATS has a different focus. From the outset, it has emphasized both cross-border barriers and barriers to local establishment. Consequently, the GATS blurs trade and investment restrictions, and covers both trade and investment rules to the extent that they limit market access in service sectors.

Given the structure of the GATS, negotiations involve parallel commitments on crossborder trade and local establishment by foreign service providers. We argue in this paper that these two modes (a simplification of the four modes actually listed in the GATS) can carry different implications for national welfare, market structure, profits, and related metrics tied to trade liberalization. In particular, given imperfect competition in services (often in conjunction with domestic regulation), realization of gains from trade liberalization is tied closely to issues of market regulation and market structure. ${ }^{3}$ This in turn means that assessment of services commitments should take into account market structure and regulatory issues that affect the degree of competition.

\footnotetext{
2 An exception is Cho (1988), who discusses Korean-U.S. negotiations on insurance and the implications of the Korean insurance cartel for the gains from trade in insurance services

${ }^{3}$ Competition in service sectors can also have important implications for trade in goods. For example, cartels in the international transportation sector can pose a significant barrier to trade in goods (Francois and Wooton, 1999). In addition, the presence of transport costs typically means prices are not fully transmitted across markets (i.e., markets are segmented). This has important implications for trade and competition linkages.
} 
The remainder of the paper is organized as follows. In Section 2 we provide some background and motivation. In Section 3 we develop a stylized model of trade in services, involving alternatively establishment or cross-border trade. In Section 4 we then examine liberalization of trade and establishment restrictions. Finally, our results are summarized in Section 5 .

\section{BACKGROUND}

As noted by Hill (1977), a critical distinction between goods and services is that services are consumed as they are produced. As a result of the flow nature of the transaction, service transactions hence involve an interaction between user and provider. Based on this element of interaction between user and provider, Sampson and Snape (1985) draw a distinction between services that require physical proximity, and those that do not. The GATS also recognizes this distinction, in that it covers trade that requires no direct proximity (the crossborder mode) and trade that involves proximity (the modes of movement of providers, movement of consumers, and foreign establishment). The most important distinction across the four types is cross-border versus local supply of services.

While GATS commitments relate to these four modes, there are also overlapping commitments in other areas under the WTO umbrella. For example, the code on government procurement provides scope for government commitments on market access to domestic service markets, to the extent that they supply the procurement market. In addition, the rules on trade-related investment measures (TRIMs), to the extent that they touch on service operations, also provide scope for overlapping commitments.

Critically, while competition policy is not formally a part of the WTO structure, competition also has an important role to play in market access. WTO members have recognized that competition policy can be relevant to the extent that it impinges on commitments made within the WTO. Hence, the recent U.S.-Japan dispute over photographic film hinged on the degree of competition in the distribution sector, while threatened U.S. action in the 1990s on Japanese auto imports also emphasizes competition in the domestic distribution and sales network. Though these touch indirectly on market access in services, there are also more direct links between competition and market access in services.

Traditionally, many of the service sectors - like banking, telecommunications, air transport, and insurance - have been heavily regulated. This regulation has sometimes, as in the case of PTTs, been undertaken in conjunction with state-sanctioned monopoly or outright 
ownership. More recently, there has been a move toward deregulation and divestment of state ownership. While the most visible example may be telecommunications, similar moves are occurring in the banking and other sectors. For this reason, GATS-related negotiations on services have taken and will take place in the context of domestic regulatory changes, and in a climate of imperfect competition.

\section{THE MODEL}

To explore some of these issues, we start with a simple model of a domestic service sector that is imperfectly competitive. The domestic oligopoly faces competition from a crossborder firm. The domestic industry is protected from foreign competition. Within this framework, we examine the implications of lowering these barriers and giving the foreign firm open access to consumers through granting the firm the right of establishment in the domestic country.

\subsection{Basic Structure}

Formally, consider the market for a homogeneous service $S$ in the home $(h)$ country. This service is provided by $n$ identical domestic firms within a regulated industry, as well as by a single foreign $(f)$ firm based overseas and facing barriers to serving the domestic consumers. The inverse demand for the service relates the market price to the total quantity supplied to the market (the sum of the outputs of the home firms and the foreign firm):

$$
p=x-y\left(n q_{h}+q_{f}\right)
$$

The revenues of the two types of firm are derived directly from the demand curve (1).

$$
R_{i}=\left[x-y\left(n q_{h}+q_{f}\right)\right] q_{i}, \quad \text { for } i=h, f
$$

Home firms face a constant marginal $\operatorname{cost} c$, while the foreign firm additionally has to pay $t$ to provide the service to home consumers. This cost may reflect cross-borer taxes, but is better viewed as a result of regulatory and other barriers to foreign operations in the home market. The foreign firm may, of course, also sell services in a third market. We are effectively assuming market segmentation here, which combined with the constant marginal cost assumption lets us proceed with the model developed in this section. Consequently, total costs and marginal costs of the two types of firms are, respectively, 


$$
\begin{array}{ll}
C_{h}=c q_{h} & M C_{h}=c \\
C_{f}=(c+t) q_{f} & M C_{f}=c+t
\end{array}
$$

The marginal revenue of the foreign firm is determined by the partial differentiation of (2), imposing the Cournot assumption that firms set quantity strategically, while assuming no subsequent reaction by competing forms (that is, $\partial q_{h} / \partial q_{f}=0$ ). The firm's perceived marginal revenue is:

$$
M R_{f}=x-y\left(n q_{h}+2 q_{f}\right)
$$

Equating marginal revenue to marginal cost for the foreign firm yields the reaction function:

$$
q_{f}\left(q_{h}\right)=\frac{x-(c+t)-y n q_{h}}{2 y}
$$

The marginal revenues of the home firms will depend on the assumed structure of the home market. Home firms are assumed to be regulated and the nature of this regulation is crucial to the firms' behavior. To bound the range of effects, we adopt two polar assumptions about regulation. The first is that the regulator ensures that the home firms behave independently, engaging in pure Cournot competition with both their domestic and foreign rivals. The other extreme is to assume that the domestic regulator promotes collusion on the part of home firms, such that they act as a cartel. In either situation, the foreign firm is at first assumed to be a Cournot competitor. ${ }^{4}$ We shall consider, below, the implications of the foreign firm being welcomed as a new member in the cartel.

Consider firstly the perceived marginal revenue for a representative, non-cooperative home firm (labeled $h n$ ), whose Cournot assumption is that its domestic and foreign rivals will not change their outputs in response to its output change $\left(\partial q_{h k} / \partial q_{h j}=\partial q_{f} / \partial q_{h j}=0, \quad\right.$ for $\left.k \neq j\right)$ :

$$
M R_{h n}=x-y\left[(n+1) q_{h}+q_{f}\right]
$$

where, using symmetry, it is assumed that all home firms choose the same level of output. The corresponding reaction function for a non-cooperative individual home firm is:

\footnotetext{
${ }^{4}$ We assume Cournot competition rather than Bertrand, as the latter would result in the competition between the foreign and home firms driving the price to the competitive level.
} 


$$
q_{h n}\left(q_{f}\right)=\frac{x-c-y q_{f}}{(n+1) y}
$$

This can be contrasted with the behavior of the representative firm (labeled $h c$ ) that is part of a regulated cartel. This firm acts in collaboration with the other home firms, each adjusting output by the same anticipated amount. Consequently the perceived marginal revenue of a representative cooperative home firm is:

$$
M R_{h c}=x-\left(2 n q_{h}+q_{f}\right)
$$

The corresponding reaction function is:

$$
q_{h c}\left(q_{f}\right)=\frac{x-c-y q_{f}}{2 n y}
$$

\subsection{Output Equilibria}

The foreign firm's reaction function (5) can be interacted with each of the home country's two possible reaction functions, (7) and (9), to solve for the market equilibrium in the noncooperative and cartel cases, respectively. When the home firms compete with both domestic and foreign firms, the equilibrium output levels are:

$$
\begin{aligned}
& q_{h n} *=\frac{x-c+t}{(n+2) y} \\
& q_{f n} *=\frac{x-c-(n+1) t}{(n+2) y}
\end{aligned}
$$

In the case of cartel behavior on the part of the home firms, the firms' equilibrium levels of output are:

$$
\begin{aligned}
& q_{h c} *=\frac{x-c+t}{3 n y} \\
& q_{f c}^{*}=\frac{x-c-2 t}{3 y}
\end{aligned}
$$

The reaction functions and the corresponding production equilibria are illustrated in Figure 1. As should be expected, home firms supply more when they act non-cooperatively. 
The foreign firm is able to free ride on the restrictive behavior of the cartel, selling a greater equilibrium quantity than when the home firms behave non-cooperatively.

\section{INDUSTRY STRUCTURE AND MARKET ACCESS}

We now consider the implications for consumer welfare and the profitability of firms when the competitive structure of the service industry is changed as a result of commitments to liberalize market-access conditions. This change can arise either through giving the foreign firm better market access or through forcing home firms to act more competitively.

\subsection{Improving Cross-border Access}

Market access for the foreign firm is improved by reducing $t$, the impediment the firm faces in servicing the home market from abroad. The foreign firm would be accorded national treatment if $t=0$, equivalent to the firm having the right of establishment in the home market where it would compete on an equal footing with the domestic firms. We shall, later, discuss the potential for the foreign firm being admitted to the domestic cartel.

We can solve for the price of the service when the domestic firms in the home country behave non-cooperatively by substituting the equilibrium outputs (10) into the inverse demand function (1), yielding:

$$
p_{n}^{*}=\frac{x-(n+1) c+t}{n+2}
$$

Profits of a firm are the difference between its revenues (2) and its costs (3):

$$
\pi_{i}=R_{i}-C_{i}, \quad \text { for } i=h, f
$$

Thus, equilibrium profits are calculated by substituting (10) into (13):

$$
\begin{aligned}
& \pi_{h n} *=\frac{(x-c+t)^{2}}{(n+2)^{2} y} \\
& \pi_{f n} *=\frac{[x-c-(n+1) t]^{2}}{(n+2)^{2} y}
\end{aligned}
$$

Figure 2a illustrates the effects of reducing the trade barrier $t$ on price $p_{n}{ }^{*}$, profits of the foreign firm $\pi_{f n} *$, and profits of the home industry $\Pi_{h n} *$ ( $n$ times the profits of an 
individual firm $\pi_{h n}{ }^{*}$, where $n=2$ in these simulations). The higher the barrier to the foreign firm, the smaller its market share and its profits, while the domestic firms enjoy a higher level of profitability. The market price rises with the barrier-home firms face less competition from abroad resulting in a less competitive price. When the trade barrier is eliminated, all firms compete on an equal basis and receive the same level of profits (so that the profits of the home industry are $n$ times that of the foreign firm).

Similar calculations can be made for the equilibrium price and profit levels when the regulated home firms behave as a cartel by substituting the equilibrium output levels (11) into (1) for the price:

$$
p_{c}^{*}=\frac{x+2 c+t}{3}
$$

and into (13) for firms' profit levels:

$$
\begin{aligned}
& \pi_{h c} *=\frac{(x-c+t)^{2}}{9 n y} \\
& \pi_{f c}^{*}=\frac{(x-c-2 t)^{2}}{9 y}
\end{aligned}
$$

Figure $2 \mathrm{~b}$ shows the impact of trade-barrier reduction on the price $p_{c}{ }^{*}$, foreign firm's profits $\pi_{f c} *$, and the profits of the cartelized home industry $\Pi_{h c} *=n \pi_{h c} *$ (where $n$ is again assumed to be equal to 2). In large respect, the lines are the same as those for the noncooperative home industry, illustrated in Figure 2a. The principal difference is that, when all barriers are eliminated (giving the foreign firm equal access to the market) the foreign firm and the home industry have equal market shares. This is because the domestic firms behave as if they were a single firm.

\subsection{Domestic Competition Policy}

We turn next to competition policy. Within our setup, a logical instrument to simulate the effects of domestic regulation is $n$, the number of home firms. If we calculate the equilibria for a cartel and for a competitive single home firm (that is $n=1$ ), we get the same outcome. Consequently, we can determine the impact of forcing a cartelized home industry to behave 
more competitively by calculating the non-cooperative equilibrium outcome for increasing values of $n$, between 1 and the actual number of firms in the industry. ${ }^{5}$

We illustrate the results of this exercise in Figure 3. In the figure, the equilibrium price $p_{n} *$ and the profits of the foreign firm $\pi_{f n} *$ and the home industry $\Pi_{h n} *$ are shown as a function of $n$, the number of firms in the home industry. The foreign firm faces a barrier to trade and hence will always have a lower level of profitability than its home counterpart in the domestic market. However, it will have higher profits, the fewer home firms that it has to compete with. Profits of the home industry are not monotonic in the number of home firms. Two home firms grab a larger share of the market than does a cartel so that, even though the overall market is more competitive, the home industry in total is better off with the increased competition. Larger numbers of non-cooperative home firms will, however, drive down overall profits in the market and lower the total profits of the home firms, despite their increased share of sales.

\subsection{The Camel's Nose Under the Tent (Admitting the Foreigner into the Cartel)}

We next consider establishment and the possibility of letting the foreigner into the cartel. Given the domestic cartel, establishment poses the immediate question-should the foreign firm be admitted into the cartel? This is a solution that has been followed in practice. Examples include the Korean and Swiss insurance industry responses in the face of U.S. pressure (See Cho 1988 on Korea). Within our framework, the interest of the foreign firm in agreeing to such an arrangement proves to hinge on the size of trading costs.

Given establishment, when is it in the interests of any of the parties for the foreign firm to be admitted into the domestic cartel? We consider the earnings of firms at various trade costs, both when the foreign firm is in competition with the cartel (subscripted, as before, by $c$ ) and when it has been admitted as a full participant in the restrictive agreement (subscripted by $a$ ). The results are illustrated in Figure 4, where the number of home firms is again set at 2 .

It is clear that, in the case illustrated, when the trade costs $\left(t>t_{2}\right)$ are high the cartel wants to keep the foreign firm out, while the foreign firm would like to have the right of establishment, even as part of the cartel. At middle trade costs $\left(t_{1}<t<t_{2}\right)$, the home cartel is feeling increased pressure on its profits from the increasingly competitive foreign firm. The

\footnotetext{
${ }^{5}$ This technique was used by the authors in Francois and Wooton (1999) in their discussion of shipping conferences and maritime trade. Also see Francois and Horn (1998).
} 
cartel would therefore like to admit the foreign firm to the cartel, an option that the foreign firm also prefers. At low trade costs $\left(t<t_{1}\right)$, the foreign firm would rather compete with the home cartel than be a part of it. The consumer always appears to lose from the formation of the cartel, even if it avoids trade costs in the process of admitting the foreign firm.

The interest of a domestic industry, in terms of favoring or opposing a foreign right of establishment, will depend on the conditions for cross-border access. The industry's position can be reversed as cross-border restrictions are negotiated down. This is because, given erosion of market power through trade, the domestic industry may find it advantageous to coopt the foreign sector by inviting them into the cartel and sharing rents. Once cross-border barriers are sufficiently low, however, the foreign view of establishment is that they prefer to play against, rather than with, the cartel. The effect of establishment on competition hence depends on cross-border access. With high trading costs, establishment may reduce welfare through profit shifting.

\section{SUMMARY}

The GATS places emphasis on two broad modes of trade-cross-border (i.e., international) trade and trade through local establishments. Cross-border trade includes movement of service providers, movement of consumers, and cross-border sales. Hence, in contrast to trade in goods, GATS-based negotiations take place on the dual margins of trade and investment concessions. Our approach in this paper has been to work with a formal model of oligopoly to examine the effects of market-access concessions for domestic and foreign firms and for domestic consumers. We have argued that the relative benefits of cross-border and establishment-related market-access concessions hinge critically on underlying issues of regulation and market structure. In particular, the interests of the domestic and foreign industry will depend, in part, on the impact that trade has on the market power of domestic firms.

We summarize our analytical results in three groupings: rather obvious, somewhat less obvious, and even less obvious. The last set of results constitutes the substantive contribution of the paper. On the rather obvious front, given an imperfectly competitive industry (alternatively Cournot or perfect collusion), less market access (i.e., greater restrictions) implies the following: the foreign service provider will have a smaller market share and profits; domestic service providers will have higher profitability; and home firms face less competition from abroad resulting in a higher home market price. 
Moving to somewhat less obvious results, we have shown that when we consider the effect of a regulatory environment that tolerates collusion among a small number of domestic firms, less competition has the following implications: the foreign firm will have higher profits the less competitive the domestic industry; profits of the home industry are not monotonic in the number of home firms; and initial moves away from monopoly can actually boost the market share and profits of the total domestic industry.

Even less obvious (and the main lesson to carry from our analytics) is the incentive for bringing a foreign firm into a dometic cartel. This involves establishment, and hinges on the set of results outlined above. It yields the following results:

- When the trade costs are high, a domestic cartel wants to keep the foreign firm out (it opposes establishment), while the foreign firm would like to have the right of establishment, even as part of the cartel.

- $\quad$ At more moderate trade costs, both the home and foreign firms favor bringing the foreign firm into the domestic cartel.

At low trade costs, the foreign firm would rather compete with the home cartel than be a part of it.

Collectively, these last results point to linkages between the degree of competition, the mode and degree of market access, and the pro-competitive effects of liberalization. When we introduce establishment in conjunction with low cross-border barriers, we find that the foreign service provider takes on the domestic cartel. This is clearly a pro-competitive result. At higher levels of cross-border trade barriers, establishment may instead lead to an equilibrium where the foreign sector is simply co-opted into the domestic cartel. This has well known negative consequences related to profit shifting. The impact of establishment on the degree of competition, and on potential gains or losses from liberalization, hinges on the underlying degree of competition (a regulatory issue), but also on barriers to cross-border trade. 


\section{REFERENCES}

Cho, Yoon Je, "Some policy Lessons from the opening of the Korean insurance market." The World Bank Economic Review, [May 1988], 241-254.

Deardorff, A.V., "Comparative advantage and international trade and investment in services." In R.M. Stern ed., Trade and Investment in Services: Canada/U.S. Perspectives. [1985] Toronto: Ontario Economic Council.

Francois, J.F., "Increasing returns due to specialization, monopolistic competition, and trade in producer services." Canadian Journal of Economics, [1990a] vol. XXIII: 109-124.

Francois, J.F., "Trade in nontradables: proximity requirements and the pattern of trade in services." Journal of International Economic Integration (now the Journal of Economic Integration) [Spring 1990b] 5(1): 31-46.

Francois, J.F.and H.Horn, "Competition policy and trade in an open economy," Tinbergen Institute discussion paper, [1998].

Francois, J.F. and L. Schuknecht, "International trade in financial services, competition, and growth performance.” [1999] CEPR discussion paper.

Francois, J.F. and I. Wooton, "Trade in international transport services: the role of competition." [1999].

Hill, T.P., "On goods and services." The Review of Income and Wealth. [1977] 23(4) December: $315-338$.

Hoekman, Bernard, "Conceptual and political economy issues in liberalizing international transactions in services.” In Deardorff, A.V., and Stern, R.M., eds., Analytical and negotiating issues in the global trading system., Studies in International Trade Policy, Ann Arbor: University of Michigan Press, pages 501-38 [1994]. 
Markusen, J.R., "Production, trade, and migration with differentiated, skilled workers." Canadian Journal of Economics, 21:3, [August 1988], 492-506.

Markusen, J.R., "Trade in producer services and in other specialized intermediate inputs." American-Economic-Review; 79:1 [March 1989], 85-95.

Sampson, G.P. and R.H. Snape, "Identifying the issues in trade in services." The World Economy 8(2) [June 1985]: 171-181.

Stern, Robert M. and Bernard M. Hoekman, "Conceptual issues relating to services in the international economy.” In Chung-H. Lee and Seiji Naha (eds), Trade and Investment in Services in the Asia-Pacific Region. Pacific and World Studies series, no. 1, Inchon, Korea: Inha University, 7-25, [1988]. 
Figure 1 Equilibrium Output Levels

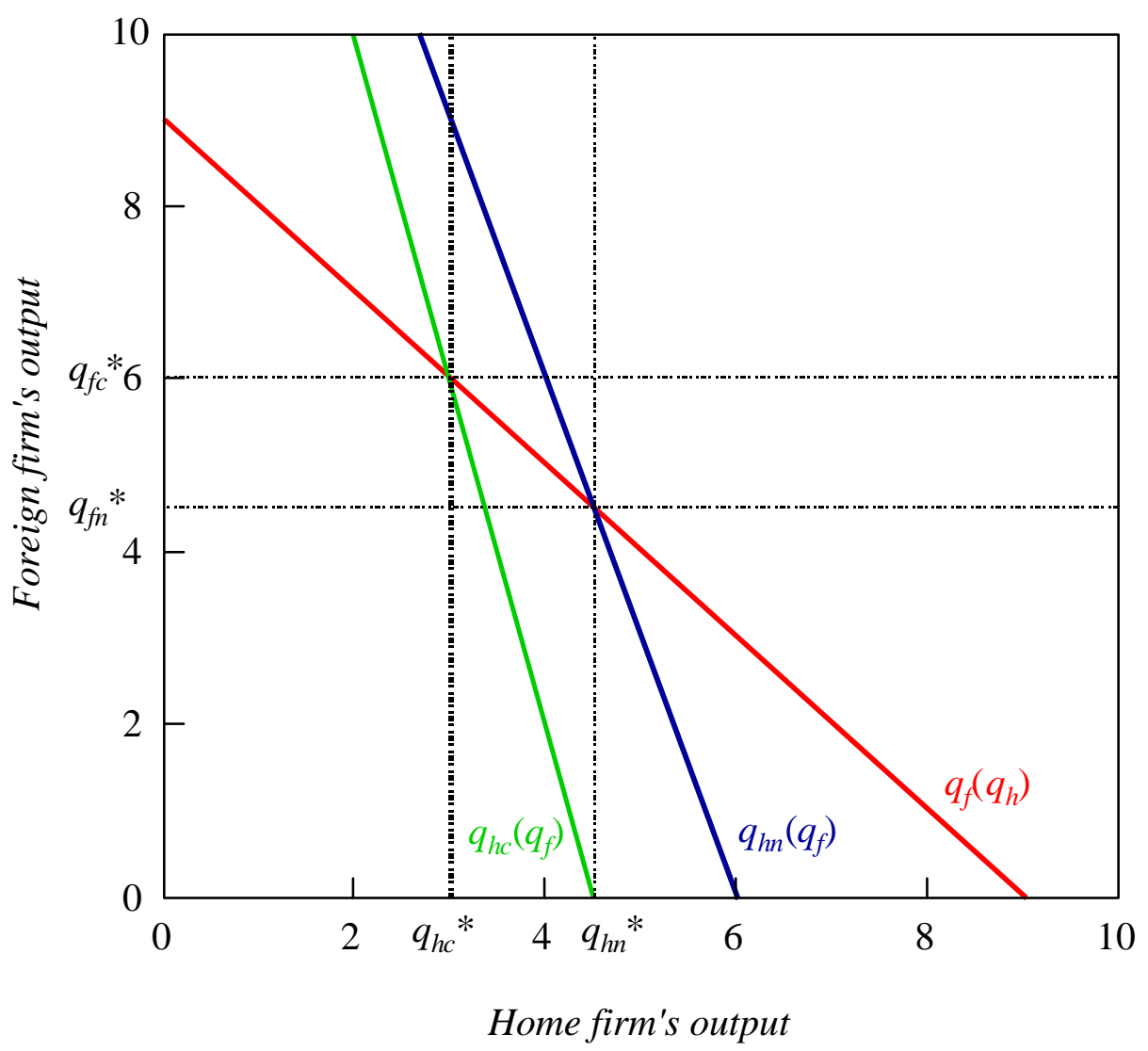


Figure 2a Improving Cross-border Access (non-cooperative home firms)

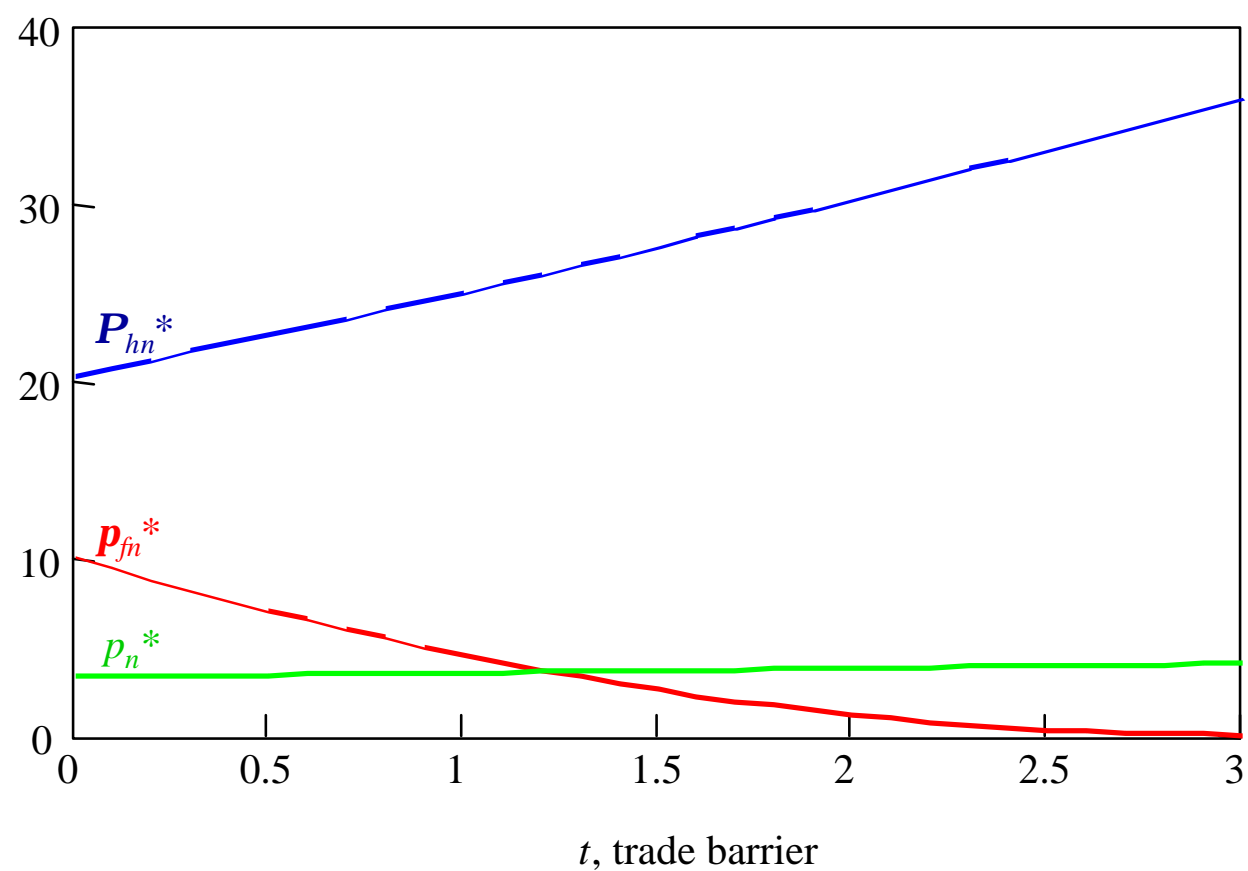

Figure 2b Improving Cross-border Access (home cartel)

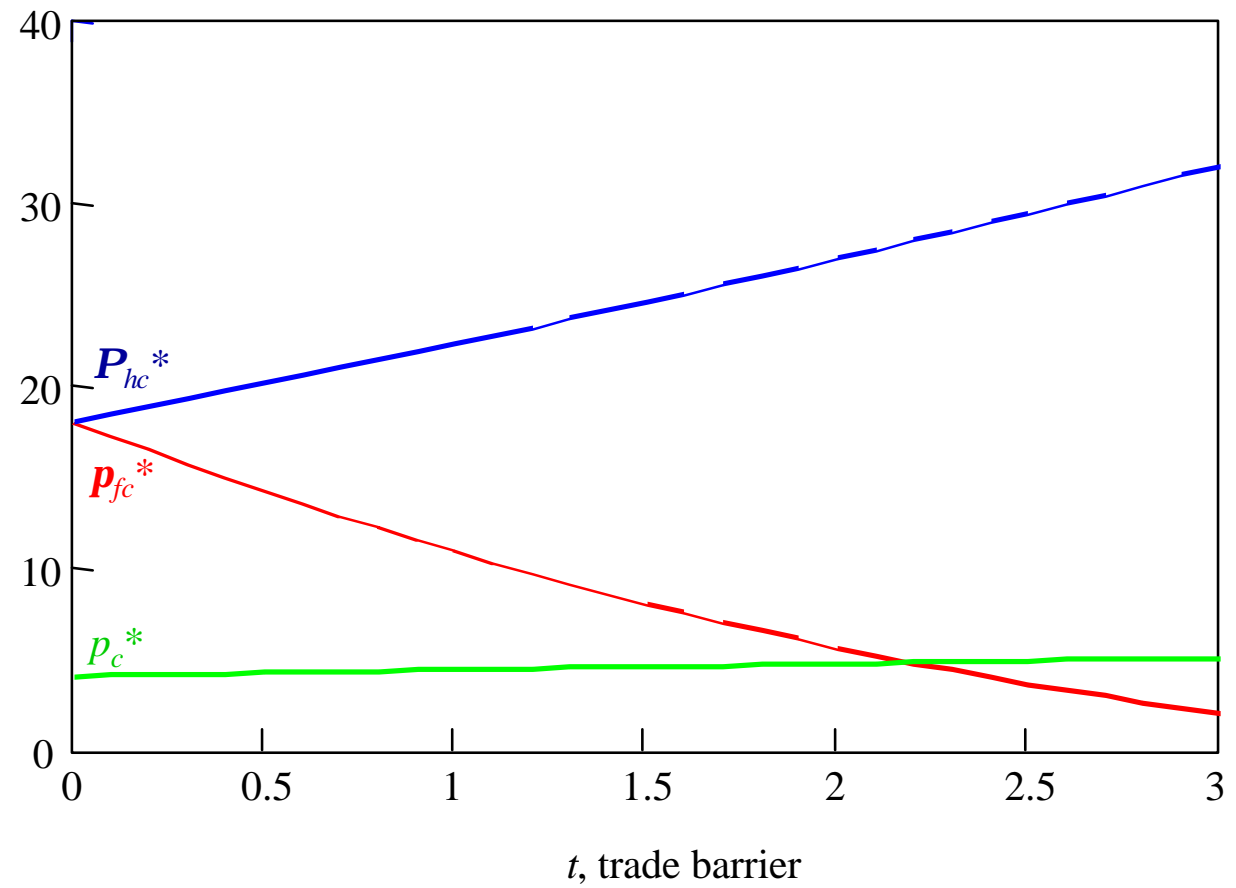


Figure 3 Encouraging Domestic Competition

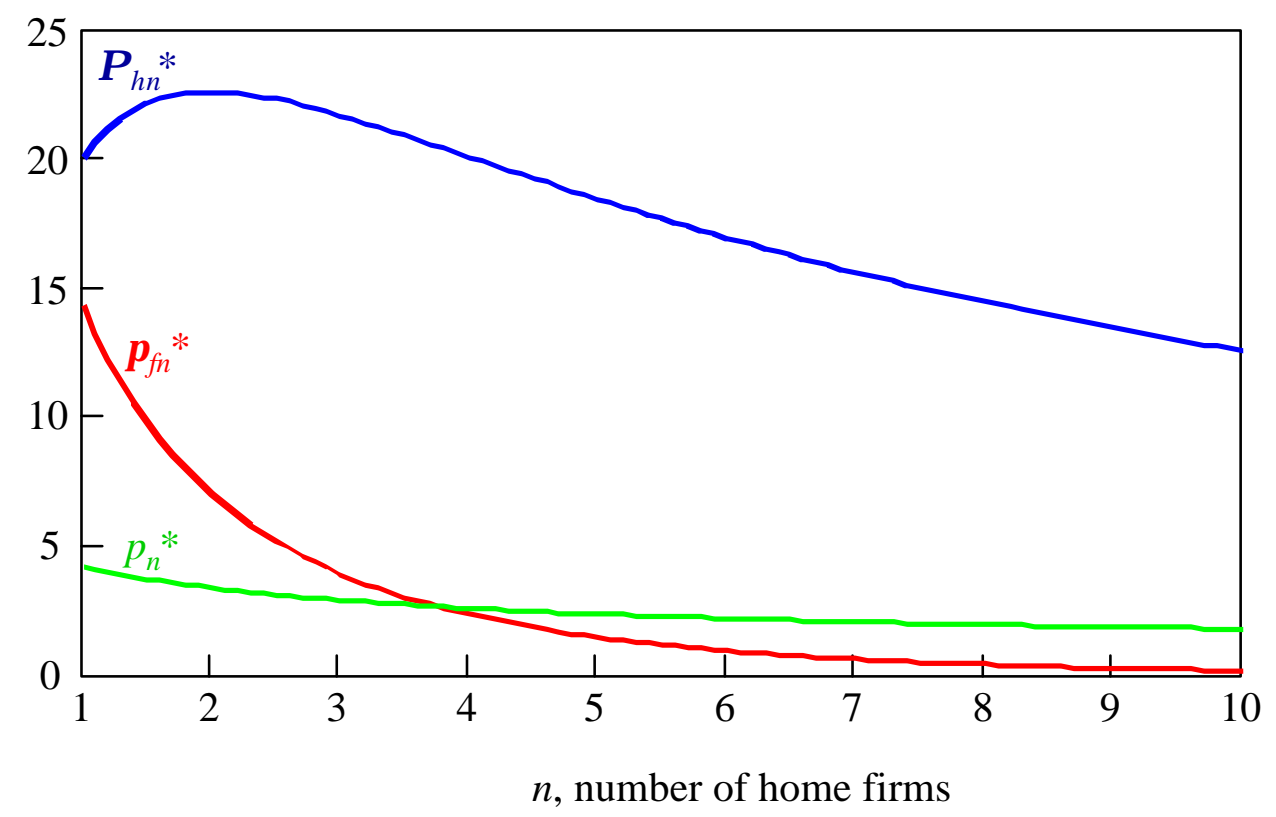


Figure 4 Choice of Regime

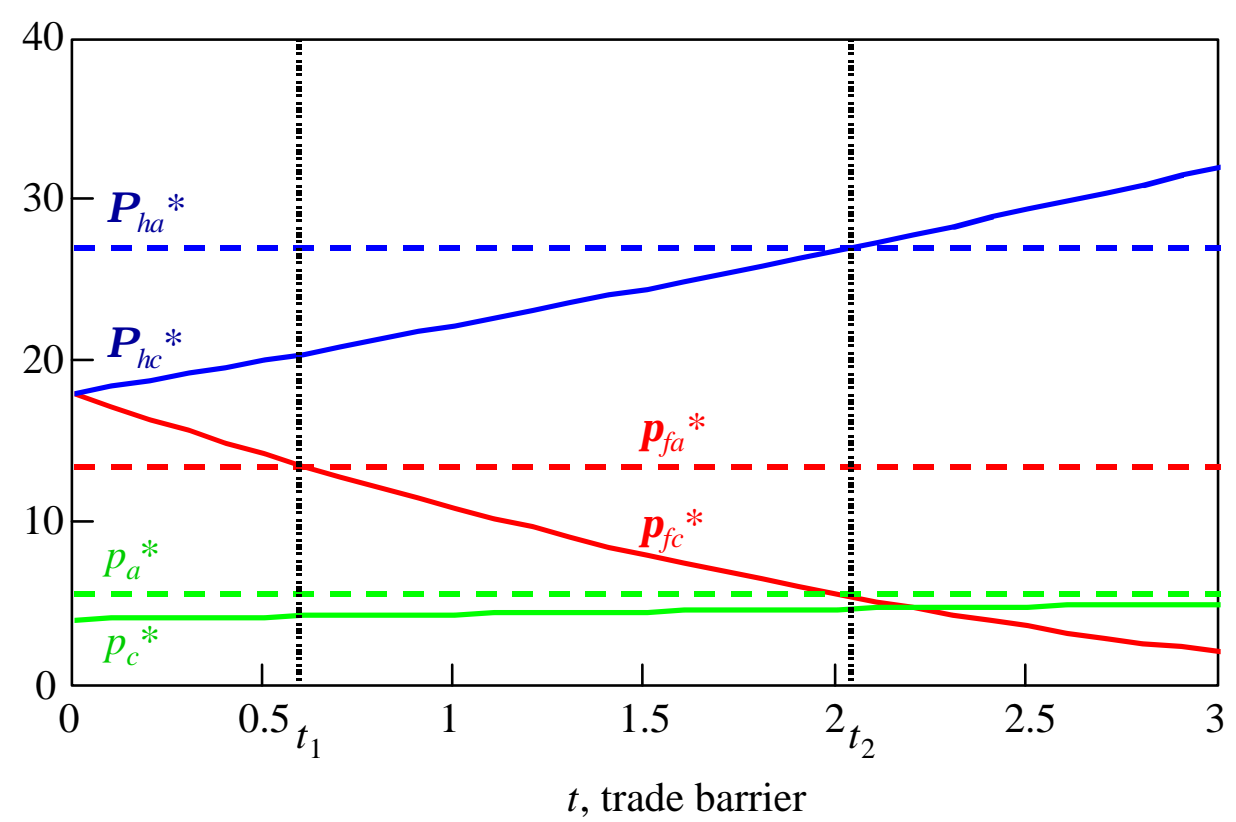


Table 1

United States Cross-Border and Affiliate Trade in Services

\begin{tabular}{||c|c|c|c|c||}
\hline \multirow{2}{*}{ Year } & $\begin{array}{c}\text { U.S. cross- } \\
\text { border exports }\end{array}$ & $\begin{array}{c}\text { U.S. cross- } \\
\text { border imports }\end{array}$ & $\begin{array}{c}\text { U.S. foreign } \\
\text { sales through } \\
\text { affiliates }\end{array}$ & $\begin{array}{c}\text { Foreign sales in } \\
\text { U.S. through } \\
\text { affiliates }\end{array}$ \\
\cline { 2 - 5 } & \multicolumn{4}{|c||}{} \\
\hline 1987 & 86.0 & 73.9 & 72.3 & 62.6 \\
\hline 1988 & 100.1 & 81.0 & 83.8 & 73.2 \\
\hline 1989 & 117.1 & 85.3 & 99.2 & 94.2 \\
\hline 1990 & 136.2 & 98.2 & 121.3 & 109.2 \\
\hline 1991 & 151.2 & 99.9 & 131.6 & 119.5 \\
\hline 1992 & 162.3 & 100.4 & 140.6 & 128.0 \\
\hline 1993 & 170.6 & 107.9 & 142.6 & 134.7 \\
\hline 1994 & 186.0 & 119.1 & 159.1 & 145.4 \\
\hline 1995 & 202.2 & 128.2 & 190.1 & 149.7 \\
\hline 1996 & 221.1 & 137.1 & 223.2 & 168.4 \\
\hline 1997 & 240.4 & 152.4 & 258.3 & 205.0 \\
\hline 1998 & 245.7 & 165.3 & & \\
\hline \hline
\end{tabular}

Source: Bureau of Economic Analysis, 1999. 